\title{
Comparison and Reference of Financing Modes of Sponge City in Foreign Countries
}

\author{
Zehua Chen \\ College of Arts, Law and Economics \\ Wuhan University of Science and Technology \\ Wuhan, China
}

\author{
Cheng Li \\ College of Arts, Law and Economics \\ Wuhan University of Science and Technology \\ Wuhan, China
}

\begin{abstract}
In recent years, sponge city construction has aroused widespread concern; the financing mode of the sponge city also has the discussion value due to its important safeguard function to smoothly carry on the construction of sponge city. The financing mode of the sponge city is divided into two parts in this paper, including the financing mode in Japan and America with the developed capital market, and the financing mode \& experience in Germany whose capital market is less developed but has the complete market economy system, and introduces significance to our country brought by the successful experiences of the financing mode of the overseas - the decentralization of the local government bond issuance right, the establishment of the effective supervision mechanism; the flexible use of bank loans, supported by the preferential fiscal policy; the establishment of the government credit rating system, perfect the credit information publicity system; charge to the residents of the installation fee of the sponge city, relief the cost to who build the devices by themselves.
\end{abstract}

Keywords-sponge city in overseas; financing mode; enlightenment

\section{INTRODUCTION}

Sponge City refers to the city has the same sponge-like characteristics, who can suck water, seepage water, clean water and store water in the rain days and release the water when it is needed, overall co-ordinate the natural precipitation, surface water and groundwater, the links between water supply and release and so on, comprehensively solve the problem of dropsy, water pollution and lack of water in the dry season. The sponge cities are called as rainwater management in foreign countries. The specific forms of rainwater management systems vary in each country, and the financing mode of rainwater facilities construction varies according to the differences of economic system and government structure. Therefore, it is necessary to combine the specific conditions of the use of appropriate financing mode to ensure the smooth construction of the sponge city.

Based on the analysis to the financing mode of the sponge city of Japan, the United States \&Germany, t following deeply discuss the content on financing experience in sponge city can be used by our country.

\section{The FINANCING Mode IN ForeIGN SPONGE CITY}

\section{A. Japanese Mode}

Japan is surrounded by sea and steam is abundant, the average annual rainfall is 1.8 times than the world average, before the construction of the sponge city, people suffered a lot from flooding problems, while the Japanese land area is small with a large population, which caused the per capita water scarcity situation Therefore, Japan's sponge city project should solve the problems of urban water dropsy, rainwater purification, storage and utilization at the same time. Japan's sponge city project is divided into two construction partslarge-scale pipe construction and private storage construction, and the financing modes for these two parts are also different. Since 1992, Japan began to build underground pipe, and has built the world's most advanced sewerage drainage system with a total cost of 3 billion US dollars till 2006, which is by far the world's largest underground drainage system. As one part of the urban infrastructure system, the fund for the construction of the underground drainage system is from the local government revenue, issuance of government bonds and borrowed fund.

After World War II, the Japanese local self-government has the right to issue bonds, and has formed as country with has largest local bond issuance of the country in the world. Japanese local bonds are divided into local government bonds directly issued by local governments and local public enterprise bonds issued by local special public enterprises. Local bond is the main body of Japanese local bonds, there are two ways: one is the most common certificate loans, which is often used when borrow from the central government funds and public enterprise financial library; one is to issue bonds, there are raising, selling and paying bonds according to the form of issuance. Japan is a centralized state, and the local government's debt is provided by the central government. In order to prevent the over-expansion and inefficiency of the local bonds caused by the local government's moral hazard, the Japanese government implements a strict management system for local bonds. The central government plan the public debt for the local government every year, including the total amount of public debt issuance, the specific purpose of the funds, distribution methods and issue amount; Local bond agreement approval system requires the lower level government to apply for a higher level government for local debt issuance plan 
every year. At the same time, the Japanese government also requires local government commercial loans can only be used for urban infrastructure construction and public utilities development, and mustn't be used as general expenses.

In the civil society, the Japanese government encourages people to build their own storage devices, there are many storage devices-underground storage devices, medium-sized storage devices and small storage devices for rain, the cost of these equipment is mainly undertaken by residents, the Government will pay different amount according to the different cities, the types of rain storage devices and the installed number. Therefore, the civil sponge city's financing mode is like that the residents undertake their own expense plus the government subsidy.

The construction financing model of Japanese sponge cite adopts the local government bonds and commercial loans, and matching management of public debt not only regulate the issuance of local government bonds to prevent the excessive expansion of government debt, but also objectively promote financing activities of the sponge city. Compare with our country, the business loan will take an important seat in the local government financing resource, while the local government bonds have never been issued. Therefore, in order to further expand the financing channels of sponge cities in China, it is necessary to learn from Japan's local government bond system, reform the issuance regulations of government bonds, release the issuing right of local government bonds.

\section{B. American Mode}

The United States has the world's most complete capital market and the most developed bond market, local governments and the state has a relatively independent bond issuance qualifications, especially the insurance of the statelevel government bonds isn't absolute control by the upper level of government; the financing of the US municipal construction and municipal infrastructure project comes mostly from the municipal bond market.

Philadelphia rainwater management financing model is a typical case of US, its financing objectives are achieved by three parts. $38 \%$ of Philadelphia's watertight areas are public sites such as urban transport, and the cost of building green rain-flood facilities is secured by government credit, which is raised by state and local governments and their agencies and authorized institutions through the issuance of municipal bonds, and Interest on municipal bonds of individual investors is exempt from income tax. The municipal bond ordinance has developed a standardized, standardized distribution system to regulate the municipal bond market in the United States. The municipal bonds are divided into general liability bonds and yield bonds based on different credit bases: the general liability bonds are issued by the government and don't relate with any specific projects, the income is supported by the government credit and tax, the bond can't be issued without the prior approval of the voters or approval by the parliamentary examination, thus, the risk is low while the return is also low; income bonds, a great variety, is issued by the lawfully established specific agency, associated with a specific project or a specific tax, and its debt service income is from the specific investment projects, the risk is high but the return is high, too.

Local governments in the United States are under the supervision of the legislature, especially the separation of the Ministry of Finance and the Ministry of Finance form an effective financial restraint mechanism, and limit the size of the debt. Commercial and industrial areas account for $16 \%$ of the city's watertight area, and the commercial development projects on private land must built with rainwater facilities according to the government regulations, which are financed by financially strong developers. Residential areas account for $20 \%$ of Philadelphia's impervious area, and the government will give subsidies to encourage residents to install rain-flood facilities around their buildings, and has introduced a costcutting policy to encourage property developers to make collection of application for investing in green canal facilities.

The above measures for the construction of the United States sponge city financing provides an important help, and provides a useful reference for our country, in summary there are three points: First, the active municipal bond market in the United States provides an efficient financing platform for the sponge city financing. Meanwhile, the scientific departmental control mechanism and the perfect bond management system guarantee the financing security of the bond market. Secondly, identify the corresponding responsible person of the investment according to the different types of urban land(public used areas, residential areas and commercial industrial zones), the investors of the public land are the national finance, the investors of the commercial industrial zone are business owners, the residential investors are residents, and clarify the responsibilities, rights and interests ; Third, make encouraging measures to encourage more people to join the sponge city construction, such as actively promote the tax relief to the construction side of the sponge city, and provide some cost subsidies and reward commendation to the residents who actively install rainwater facilities, as a matter of fact, which promote the construction progress of the sponge city project.

\section{German Mode}

The sponge city construction belongs to the urban infrastructure construction, there are two kinds of funding sources for Germany's urban infrastructure construction: first, roads, railways, natural gas are the infrastructure that must be centralized and unified, which use the unified investment by the state; the second is the general infrastructure construction funds, they are financed by government grants (40\%), revenues from utilities, local investment, and fees from the users and residents. Sponge City project financing model adopts the second type, the government funding and utilities revenue are from government finance, the local investment channels and the residents charge system need to be further explored.

Local investment includes the municipal and county selffinancing and the state government-funded investment, it is called as the financing platform for government that the German government and its coordinate organizations provide funds to the borrower through banks or government 
organizations themselves. Germany is a federal state with a market economy. The administrative regions are divided into three levels: the federal government, the state and the local level. The states are relatively independent with special emphasis on free competition and very little involvement of the state-owned capital in the business sector. Therefore, a very complete market economy system was formed and the credit system of market main body is also very perfect.Unlike the Anglo-American countries, Germany's capital market is underdeveloped, government financing adopts the indirect financing based on the project to promote the banks financing and commercial banks financing, this kind of loans is supported by the unconditional guarantees from government, enjoys duty-free treatment, and serves wide broad objects without limits in public welfare areas such as the urban infrastructure and so on. The German banking system adopts a mixed operation system, which integrates the functions of commercial banks, investment banks and insurance industry. The business fields are diversified and the information is exchanged between various fields, thus the phenomenon that all the businesses of an enterprise are handled by the same bank, and then the bank can comprehensively supervise the daily economic activities of the borrower, the information between banks and borrowers are fully symmetrical, the risk of banks is low so that they can deal with loans quite easily.

According to the non seepage area of building, Germany implement the charge system, 1.84Euros per square meter, to the residents for discharging rain water $\&$ using the rain water facilities, and give reduction and exemption on water and other privilege to the residents who installed the green roof, underground water storage and rainwater purification devices such as the rain water detention and storage devices according to the construction requirements of the sponge city. Now, the German people show a high enthusiasm to support the construction of sponge cities, most of the new buildings are laid green roof, many families make their own rainwater storage devices, such as the laying of sewage interception equipment on the ground, the installation of the underground storage tank .

Germany, through the government funding, utilities revenues, local investment, charging from the user and the residents, successfully raises sufficient funds to build the sponge city, which not only illustrates the direct financing mode, adopted by England, America and France with the developed capital markets in form of bonds \& stock issuance, is effective, but also indicates that the suitable indirect financing mode, used in countries with undeveloped capital market in form of bank loan, is efficient; the emphasis is to build a sound credit system and preferential taxation policies matching with them. In addition, Germany's rainwater charging system works better and this system is not the main financing way of sponge city; its purpose is to stimulate people's enthusiasm in sponge city construction and improve people's awareness of ecological protection and energy-saving cycle.

\section{INSPIRATION TO CHINA FROM OVERSEAS SPONGE CITY} FINANCING EXPERIENCE

\section{A. Decentralize the Local Government Bonds, Establish An} Effective Monitoring Mechanism

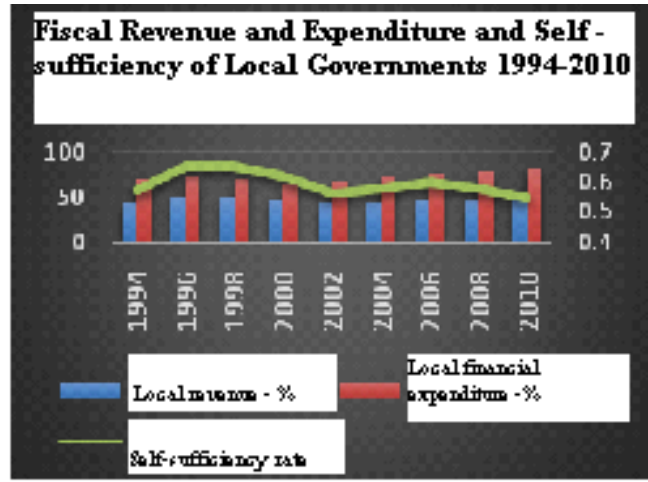

Data source: collect by the author according to the relevant data

From 1994 to 2010, the income of China's local government finance is low for a long term and the selfsufficiency is low shown in the figure. In general, China's local government revenue comes from the central government funding, land transfer revenue and debt financing, and the debt financing includes commercial loans and bonds issuance rely on City Investment Corporation. Based on the financial situation of the local government, the sponge city financing channels must adopt another way but can't rely on the existing model. Japan and the United States have the experience of issuing local government bonds with different forms due to the political differences. Japan, adopting the centralized system, issued local government bonds; while the United States, adopting the separating federal system, issued municipal bonds From this view, it is known that the key to the development of the local government bond market is the implementation of an effective supervision and control mechanism. If China adopting the democratic centralism system can build a sound regulatory system, it can also have the conditions for issuance of local government bonds. In view of China's national conditions, we should set up the central, local, regional threetier regulatory system; establish the annual approval system for local bond. The daily supervision work at the central level may be carried out by the central financial department or the specialized Finance Ministry of the Sponge City, and the National People's Congress shall conduct regular inspections on the implementation of the supervision work. The local finance and local people's congresses shall supervise the issuance of bonds under their respective localities; the local audit inspection department is responsible for the statistics and analysis of the local government bond market data to provide a basis for higher supervision. The main work of the annual approval system for local bonds is to draw up the plan for issuance of bonds in the next year and submit them to the higher level government for examination and approval at the end of the year. The higher level government will check and evaluate the total amount of issuance, the number of issued bonds and the specific use. 


\section{B. Flexible Use of Bank Loans, Supplemented by Preferential Fiscal Policy}

The financing scale of the Sponge City is very large, which needs for a variety of financing tools used in accordance with the appropriate proportion to reduce the occupation of other municipal construction project funds, reduce the risk of a single financing. Like Germany, whose indirect financing mode of bank loans is fully utilized in many fields of the national economy, China can also draw lessons from it, and take the indirect financing model as a supplement to the direct financing mode. At present, China's local governments have borrowed money from banks to finance the construction of public utilities, but there are still some shortcomings in supporting policies. On one hand, the sponge city project should be exempted from the interest of the bank loan, sponge city is the majority of pure public welfare projects plus part of the quasi-public welfare projects, it is an urban infrastructure to improve quality of life, its construction is not profitable and the future cash return is low, the Government should support the sponge city financing activities via supporting the introduction of interest rate cut policy; On the other hand, the sponge city will bring some fees after being put into use, this part of the income should be exempted from tax, because this part of the income needs to be used to repay the debts of the pre-financing, which forms one part of the local government's income.

\section{Establish a Government Credit Rating System, Improve the National Credit Information Publicity System}

Commercial loan is an important channel for sponge city financing. The main reason for the success of the German indirect financing model is that Germany has a perfectly competitive market economy system, and information exchange among the daily operations of the mixed bank has formed a perfect market credit system. In China's sponge-city financing activities, local governments will act as guarantors of local bank loans; it is necessary to improve the transparency situation of the financial balance of payments and bring the local government credit information into the national credit information system to increase the credibility of local governments while avoiding excess accumulation of local government over-lending and reducing the risk of borrowers.

At present, China has established a national enterprise credit information publicity system, which will public the enterprise instant information, enterprise annual report information, business anomalies information in the network, but the existing problem is that some business information on the selective disclosure, involving enterprise key business information such as Shareholders and investment information, the main business income, the number of employees, total tax and net profit options and so on, which in fact caused the enterprise information publicity system dummy, which can't provide more valuable business operating conditions reference data. In view of this, China should not only bring the credit status of the government into the credit information system of the country, but also need to concern about the government and corporate financial data publicity details, require the key information must be open to information publicity work. In addition, it is necessary to strengthen the information communication among various government regulatory bodies such as industry and commerce, credit and insurance, so as to provide a reliable reference for lenders when they apply for commercial loans, comprehensively and in real time reflect the business conditions of the enterprises and the financial situation of the government, so as to reduce the credit risk and improve the utilization efficiency of social capital.

\section{Sponge City Installation Fee Shall Be Charged to the Residents and the Fee for Self-Built Installation Shall Be Reduced}

Historically, China has not levied rainwater pollution fees and sewage treatment fees to the residents, so we can't charge from the residents according to the building impervious area like developed countries in Europe and America, but the sponge city puts forward new requirements to the performance of the building, the cost of the new residential area will be increased, the original residential area is also facing a large number of roof, ground and underground engineering transformation, resulting in considerable cost costs, the residents who is the owner and the beneficiaries of sponge city project should bear the rain-flood transformation costs. At that time, the Government will introduce the relevant charging rules, including the cost of roof green pool, ground drainage and seepage engineering costs, underground water storage equipment and installation costs, for the devices built by the residents themselves, the engineering fee of the sponge city will be discharged according to the actual storage, water seepage effect; in order to ensure that self-built devices on the rain water management play a practical effect, the local government departments should regularly test these devices, and truthfully give feedback of the test result to the residents and flexibly adjust the charging policy.

\section{CONCLUSION}

By comparing the financing experience of the developed countries in Europe and the United States, we can draw the conclusion that whether the direct financing mode or the indirect financing mode both can guide the success of sponge city financing activities, the key is to combine the political system, economic system and market development status; In addition, the relevant policies and laws and regulations should also be improved as a system of protection.

\section{REFERENCES}

[1] Chaoxuan Liao, Aiguo Gao, Enhao Huang. Enlightenment to the sponge city construction in China from foreign rainwater management [J]. Water resource protection, 2016,32(1):42-50 .

[2] Lichun Liu. "Sponge" Germany[j]. City geography, 2015,(8):10.

[3] Junqi Li, Yang Liu, Wu Che etc.. Rain water management mechanism and policy in developed countries[J]. Construction of City and Town, 2011,(8):75-76.

[4] Kaijiang, Dou Yan, Meiying Yang. The financing mode of the local government of our country under the international experience perpective[J]. Southwest Finance, 2011,(7):56-57.

[5] Danjie Wu, Shengze Yan, Youhua Li etc.. Research on the emerging trend and practice of the sponge city with Chinese Characteristics[J].China Soft Science, 2016,(1):79-95. 
[6] Chengxi Liu. Comparison and reference of foreign infrastructure investment and financing mode [N]. Global market information herald, 2016, (4). 